\title{
The Effect of Religiosity on the Improvement of Customer Loyalty Towards Islamic Banks
}

\footnotetext{
Submitted 20/07/20, $1^{\text {st }}$ revision 16/08//20, $2^{\text {nd }}$ revision 27/08/20, accepted 30/09/20 Sunaryo $^{1}$, Soegeng Wahyoedi ${ }^{2}$, Achmad Sudiro ${ }^{3}$, Sudjatno ${ }^{4}$

\section{Abstract:}

Purpose: The main objective of this research was to analyze the effect of religiosity as a moderator on the relationship between service quality, customer trust, satisfaction, and loyalty towards Islamic banks in Jakarta.

Design/Approach/Methodology: The research sample was 240 respondents (Islamic bank customers) taken by purposive sampling. The data were analyzed using Partial Least Square (PLS), a covariance-based SEM with WarpPLS 6.0 software. In general, the structural model fit carried out in this research was adequate, and the measurement model met the validity of internal consistency reliability.

Findings: The results showed that the variables of service quality, customer satisfaction, and religiosity had a positive and significant direct effect on customer loyalty. However, the direct effect of customer trust on customer loyalty was not significant. Meanwhile, religiosity had a positive and significant effect on the relationship between service quality and trust in customer loyalty. Also, religiosity failed to moderate the effect of customer satisfaction on customer loyalty.

Practical Implications: This research is expected to contribute not only to the development of literature but also to the banking industry, especially Islamic banks, in developing marketing strategies related to the impact of religiosity so that the promotion of religious activities that are meticulous and sensitive to customers can help spread and strengthen moral norms of ethical behavior in understanding Islamic banks.

Originality/Value: This study is original research that provides references to the factors that influence customer loyalty in Islamic banks, especially in Islamic countries, where the role of culture is powerful.
}

Keywords: Service quality, customer satisfaction, loyalty, religiosity, Islamic banks.

JEL codes: M31, M39.

Paper Type: Research Article.

\footnotetext{
${ }^{1}$ Corresponding author, Department of Management, Faculty of Economics and Business, Brawijaya University, Malang, Indonesia, e-mail: sunaryonadi@ub.ac.id

${ }^{2}$ Department of Management, Faculty of Economics and Business, Krida Wacana Christian University, Jakarta, Indonesia, ORCID: 0000-0002-9107-3621, SCOPUS : 57211917138, email: swahyoedi@ukrida.ac.id

${ }^{3}$ Department of Management, Faculty of Economics and Business, Brawijaya University, Malang, Indonesia, e-mail: achmadsudiro@yahoo.com

${ }^{4}$ Department of Management, Faculty of Economics and Business, Brawijaya University, Malang, Indonesia, e-mail: psudjatno@yahoo.com
} 


\section{Introduction}

The service sector, including banking, is important for the economy of countries (Beck and Levine, 2000). This sector can create employment opportunities and stimulate economic growth (Antonio, 2001). World Bank data (2017) demonstrated that the contribution of service sector to the world's GDP in 2016 was $66 \%$. Based on World Bank data, the contribution of service sector in Indonesia to GDP in 2016 was $45 \%$ outperforming the industrial sector at $41 \%$ and the agricultural sector at only $14 \%$. Liberalization and deregulation of the financial sector, advances in information technology and improved communication systems have created a tight competition among banking institutions, especially Islamic Banking.

The rapid development of Islamic Banks today is apparently inseparable from the role of the Organization of Islamic Conference (OIC) which, since the 1970s, has encouraged its member countries to improve the people's economy in their respective countries through the Islamic Development Bank (IDB) centralized in Jedda (Nita et al., 2016). The development of Islamic banks currently occurs not only in countries with a majority Muslim population, but also in countries with nonMuslim populations. Based on Thomson Reuters Global Islamic Index data (2018), the potential for global Islamic banking activities reached US \$2,438 trillion in 2017, and it is estimated to reach US \$ 3.809 trillion in 2023. Meanwhile, global Islamic banking assets in 2017 reached up to US \$ 2, 19 trillion. In European countries like Britain and Luxembourg, where the majority of the population is nonMuslim, the growth of Islamic banking is very rapid. Furthermore, Islamic banking has become an alternative in various countries, ranging from Sweden to Australia. In fact, a number of countries in Asia also have Islamic banking industries; such as in Indonesia, Singapore, Malaysia, Hong Kong and China. Likewise, South Korea and Japan have also shown interest in Islamic banking industry (Republika Onlne, 2010).

The development of Islamic banks in Indonesia is increasing every year (Indonesian Banking Statistics, 2019) although it is still proportionately low compared to conventional banks. Viewed in terms of population, Indonesia is a country with the largest Muslim population in the world reaching 229.62 million people (databoks, 2019). Therefore Indonesia has a very large Islamic banking market potential. However, the participation of Muslim society in Islamic banks is still low. This was proven in 2018 in which there were 29.01 million Islamic bank customers, or only about $10.8 \%$ of Indonesia's total population of 269 million. Based on UNCEIF Central Bank data, the total Islamic banking asset in Indonesia compared to Islamic countries (Organization of Islamic Cooperation) and Malaysia still shows the smallest amount of only 1.4\%. Meanwhile, the total Islamic banking assets in some other Islamic countries (OIC) are as follows; Kuwait 21.6\%, Bahrain 14.4\%, Qatar $14.4 \%$, UAE $11.8 \%$ and Malaysia 11.3\% (Awan, 2007). In addition, looking at Islamic banks globally, Indonesia's asset percentage is still very low, with only $1.9 \%$ and ranked $8^{\text {th }}$ along with Bangladesh. Iran occupies the first position by 
contributing $32.1 \%$ in global Islamic banking assets followed by Saudi Arabia with a contribution of $20.2 \%$ (IFSB, 2019).

Although Indonesia's Islamic banking market share is still small by 3\% (Yogyakarta Republika Online, 2010), there is an increase in its growth every year. This shows that there is a development in marketing and an increase in demand for Islamic banking in Indonesia. This also illustrates that there is customer loyalty to Islamic banking despite its low percentage. The low level of loyalty is possibly caused by inadequate service quality, trust, satisfaction as well as lack of awareness of Muslim community in Indonesia towards Islamic banking. In addition, the possibility of the problem is also caused by the lack of understanding of Muslim community regarding the Islamic bank products, systems and observance of sharia law, or low level of religiosity. Similarly, Wan Sabri (2001) showed that there were Muslims who began to put aside Islamic values and ethical norms in all aspects of life. In addition, a study conducted in Jakarta showed that the number of Islamic bank customers was only 7\%, while the number of conventional bank customers was 93\% (Infobanknews, 2008). In addition, a study conducted by Yusuf (2006) in six major cities in Indonesia (Medan, Bandung, Semarang, Jakarta, Makassar and Surabaya) also supported the statement.

The study showed that only $23 \%$ of respondents were Islamic bank users, while $33 \%$ were conventional bank users, with the remaining $44 \%$ were both Islamic and conventional bank users. Furthermore, the results of the study also showed that only $20 \%$ of respondents were loyal to Islamic banks, the remaining $80 \%$ were loyal to conventional banks. This situation demonstrates that the participation and awareness of general public towards Islamic banks is still low. Hence, it exemplifies that customer loyalty to Islamic banks is also still low.

In a tight market competition, companies including the banking industry should not only develop better infrastructure and provide additional benefits, but also create a long-term relationship with their customers. For this reason, attention to customer loyalty is a major goal that can be considered as a key factor in increasing market share and creating competitive advantages for every business (Beerli et al., 2004; Luarn and Lin, 2003; Subkhan, 2005; Durkin, 2005; Jaiswal and Niraj, 2007). Loyal customers are considered the key to success and survival in most service businesses (Rahman, 2005). Therefore, keeping customers loyal is very important as it can create strategies for competitive advantages.

There are various factors affecting customer loyalty that have been studied and discussed intensively; including religion or religiosity (Dusuki and Abdullah, 2007; Rahman, 2009; Okumus and Genc, 2013; Razimi and Romle, 2017), trust (Hoq et al., 2010; Amin et al., 2013; Rizwan, 2014; Nejad et al., 2014; Mahardika, 2018), customer satisfaction (Kuusik, 2007; Naeem et al., 2009; Ravichandran et al., 2010; Basalamah et al., 2010), company's image (Gan et al., 2006; Kandampully and Hu, 2007), service quality (Umar and Tahir, 2010; Cloud and Bukhari, 2011; Echchabi 
and Aziz, 2012; Echchabi and Olaniyi, 2012; Kiseleva et al., 2016; Basalamah et al., 2018), and brand image (Kuusik, 2007; Hsieh and Li, 2008; Marzler at al., 2008).

The Islamic banking system adopts profit sharing therefore, trust, openness, honesty and fairness are the main keys to achieve its business goals. Reichheld and Schefter (2000) argued that to gain customer loyalty, the main factor that must be considered is trust. Furthermore, Zineldin (1995) proved that $98 \%$ of the companies studied considered that trust and confidence are very important in choosing banks. Similarly, Harris and Goode (2004) stated that trust is a key and major factor in supporting customer loyalty. Therefore, trust is a very important and valuable asset in business, especially in Islamic banking industry. Trust is also seen as a key element in forming relationships with customers and maintaining the company's market share (Graf and Perrien, 2005). In addition, trust is a factor that determines the success or failure of a company (Shalhaib, 2006). However, there are still public doubts towards Islamic banking; such as the purity of products offered and the sincerity of employees (Haniffa and Hudaib, 2007). Moreover, Islamic banking still has a negative image, and public awareness of Islamic banking is still low (Karim and Affif, 2005; Ariffin et al., 2005).

A study conducted by Indonesian Business Intelligence Unit (BIIU) (2009) in Jakarta on perceptions of the Islamic banking system showed that $62.1 \%$ of respondents were hesitant about the transparency of fund security (https//:www.bisnis.co.id adopted in 2019). In addition, several empirical studies highlighted that trust had a positive effect on customer loyalty (Lin and Wang, 2006; Ndubisi et al., 2007; Kuusik, 2007; Nejad et al., 2014; Rizwan et al., 2014). Nonetheless, in another study, trust had an insignificant direct effect on loyalty (Ball et al., 2004) and also had a negative relationship with customer perceptions (Jarvenpaa et al., 2000). Furthermore, a study conducted by Setyawati and Raharja (2018) found that not all dimensions of trust were related to customer loyalty. Amin et al. (2013) found a positive effect between trust and loyalty in their research in Malaysia, yet this effect was stronger for non-Muslim customers compared to Muslim customers.

In the marketing literature, one main element of business success is maintaining customer satisfaction (Chaopraseit and Elsey, 2004; Mostaghel, 2005). According to Jones and Sasser (1994), satisfaction is important because it can be used as a determining factor to support customer loyalty. Meanwhile, Wirtz (2003) stated that satisfaction can encourage customers to repeat purchases, be loyal, submit positive word-of-mouth information and increase long-term profits. Some previous studies such as Lin and Wang (2006), Gan et al. (2006), Ndubisi et al. (2007), and Kuusik (2007) stated that customer satisfaction and loyalty have a positive relationship. Furthermore, Ruyter and Bloemer (1999) stated that satisfaction is the most important determinant of customer loyalty. However, other studies showed that high levels of satisfaction do not always indicate loyalty or create loyal customers (Rowley and Dawes, 2000; Spiteri et al., 2004). Likewise, Kassim and Souiden 
(2007) concluded that satisfaction is not the only determinant of loyalty in retail banking.

The strategic key to success and survival of most service businesses is to pay attention to the service quality given to their customers (Shafie et al., 2004; Amin and Isa, 2008). Hsin et al. (2008) stated that there was a relationship between service quality and loyalty, meaning that customer satisfaction towards the goods or services received would lead to loyalty. Basalamah et al. (2017), in their research in Makassar, found that service quality had a positive effect on Islamic bank customer loyalty. Furthermore, Awan and Bukhari (2011), in their research in Pakistan, found that the service quality was more dominant in its effect on loyalty compared to religiosity. Meanwhile, Echchabi and Olaniyi (2012), in their research in Malaysia, stated that customers who enjoyed good service quality would become loyal to Islamic banks. Another study stated that service quality was a major important factor in determining satisfaction and creating competitive advantage (Othman and Owen, 2002; Amin and Isa, 2008). Similarly, studies conducted by Luo and Bhattacharya (2006), Pollack (2009), and Naeem et al. (2009) argued that excellent service quality would have an impact on satisfaction, and subsequently would have an impact on customer loyalty. However, the relationship nature between these two constructs was still unclear regarding which was better between service quality and satisfaction in affecting customer loyalty (Saurina and Coenders, 2002).

The presence of Islamic banking proves that there is a strong (positive) relationship between religion and economic activities (behavior) in Muslim community (Parmudi, 2005). Meanwhile, in the general theory review of marketing ethics, in addition to service quality, religion is also one factor affecting the decision making process (Tournois and Mouilot, 2002). Sheth and Mittal (2004) stated that religiosity affected consumer behavior mainly through trust, in the form of consumer personality. Branas-Garza et al. (2006) examined the effect of religiosity (Catholicism) on trust and revealed that trust had a positive relationship with religiosity. Genc (2013) argued that religiosity is a key factor of customers to use or choose Islamic bank products and services.

Based on this phenomenon and the relationship gap between service quality, trust and satisfaction on loyalty, this research aimed to analyze the impact of religiosity as a moderator on the relationship between service quality, trust, satisfaction and customer loyalty towards Islamic banks in Jakarta. Religiosity as a moderator in this research was chosen as a solution to overcome the gap problem. In addition, religiosity is rarely studied in Islamic banking, especially as a moderator.

\section{Literature Review and Hypotheses}

This section presents a brief overview of the conceptual foundations of research and theoretical studies explaining the constructs in empirical studies and the 
relationships between proposed variables in forms of conceptual frameworks of research models and formulated hypotheses.

\subsection{Relationship Marketing}

Some theories developed in this research are about loyalty, yet the related basic assumption is relationship marketing theory adopted from Schneider's (1980) thinking in which $\mathrm{h}$ examined how companies focused more on retaining existing customers than on attracting consumers. Palmaiter et al. (2006) explained the effect of correlation on loyalty through a meta-analysis study and found that correlation would result in customer loyalty, as shown in the diagram below.

Figure 1. Customer-Focused Relation

Relational Mediator Meta-Analytic Framework

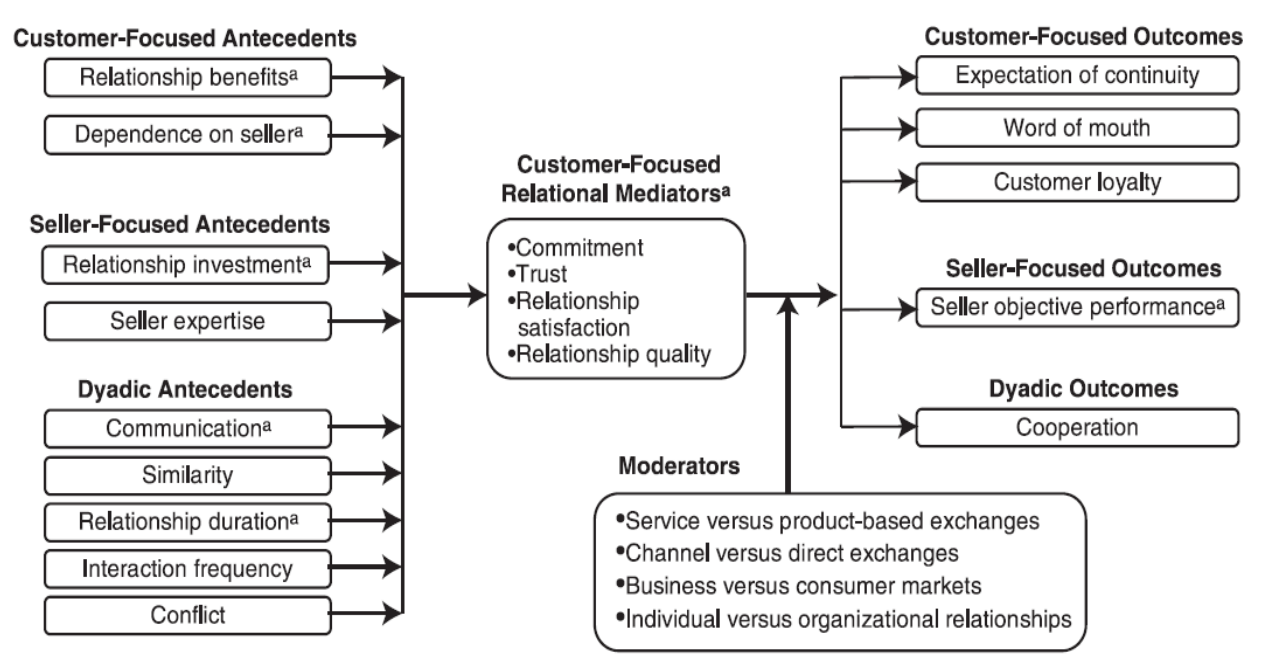

Source: Palmaiter et al., 2006.

Leverin and Liljander (2006) revealed that although marketing relationships impacted bank customer loyalty in Finland, it would be different if the customers were segmented. However, Castro (2006) found that in recent years, the marketing program of correlations received harsh criticism related to the dissatisfaction of the marketing programs' results in some companies' relationships. According to Dowling (2002), dissatisfaction is when customers are not motivated to build relationships because they are busy, are not interested, or think that it is a waste of energy.

\subsection{Loyalty}

Beerli et al. (2004), Michael and Bandyopadhyay (2007), Casalao et al. (2008), Wugayan and Pleshko (2010) used the concept of customer loyalty towards bank through the customer loyalty approach. Kotler and Keller (2016) argued that 
customer loyalty is a commitment to re-purchase or continue using a product or service. Moreover, Marshall (2010) defined customer loyalty as a deep commitment to re-purchase a product or service that they enjoy consistently in the long run. This concept was then modified by Griffin (2004) in which he defined customer loyalty as a randomized purchase reflected by the continuous purchase of a decision-maker unit. This continuous purchase is interpreted as a repeated purchase.

Business development in the future will depend on increasing customer loyalty behavior. As Hayes (2011) has shown, business models may vary, the main factor driving business growth and company value is customer loyalty. Lee et al. (2010) stated that customer loyalty is an important strategic goal for all marketing managers. Also, loyalty is a strategic goal for the company and a determining variable in its marketing performance. Al-Wugayan and Pleshko (2010) stated that the company's marketing performance is determined by loyalty caused by satisfaction, and satisfaction results in repurchase action.

Lovelock and Wirtz (2011) explained the ways to build customer loyalty. First, companies need a strong foundation to create customer loyalty, including targeting the portfolio of customer segments, attracting the right customers, and providing a high level of service quality and satisfaction. Second, companies need to develop a close relationship with customers, and third, companies need to identify and eliminate the factors that cause the loss of existing customers. Amin et al. (2013) used behavior and attitude as measures of loyalty. Boonlertvanich (2019) also used the same measures, i.e., conduct re-purchase with the bank, recommend the bank to others, be willing to continue to use the bank service in the future, and believe that the bank provides good services.

\subsection{Service Quality}

The strategic key to most service businesses' success and survival is to pay attention to the service quality to the customers (Shafie et al., 2004; Amin and Isa 2008). Furthermore, Dusuki and Abdullah (2006) stated that service quality's importance is to attract more customers. Hsin et al. (2008) found a link between service quality and loyalty, meaning that if the customer were satisfied with the goods or services received, it would cause loyalty. Thus, in their study in Makassar, Basalamah et al. (2017) found that service quality had a positive effect on Islamic bank customer loyalty. Another study stated that service quality is a major factor in determining satisfaction and creating a competitive advantage (Othman and Owen, 2001; Amin and Isa, 2008). Also, studies conducted by Luo and Bhattacharya (2006), Pollack (2009), and Naeem et al. (2009) argued that excellent service quality would affect satisfaction and, subsequently, on customer loyalty. Nonetheless, the relationship between the two constructs is still unclear, which is better between service quality and satisfaction in affecting customer loyalty (Bitur and Hubbert, 1994; Saurina and Coenders, 2002). 
Kashif et al. (2015) stated that service quality measurements made through SERVQUAL are inappropriate since service quality is more a cultural phenomenon. Thus, service quality indicators will differ in different cultures. Measuring service quality using the same indicators in a different culture, such as SERVQUAL, will provide different applications in different contexts. In the context of Islamic banks, Othman and Owen (2001) introduced six dimensions to measure the quality of Islamic financial institutions' services. This model used the five dimensions covered in SERVQUAL and added a dimension of compliance (adherence to Islamic law). The Othman and Owen model (2001), known as the CARTER model, was formed with six dimensions, namely Compliance, Assurance, Reliability, Tangible, and Responsiveness.

Compliance is defined as following the rules or laws established by God, namely Sharia. Assurance is employees' extensive knowledge of products, skills in delivering services, friendly attitude/polite, and their ability to achieve customer trust. Responsiveness involves the willingness of organizational resources to assist customers and provide services responsively and precisely. Tangible (physical evidence) concerns the organization's visible physical facilities, the equipment used, and the communication materials used by the service organization. Empathy covers the organization's concern for the intentions and needs of customers and good communication and special attention to the customers. Reliability can deliver the promised performance to the customer reliably and accurately. Therefore, this research's service quality used Carter's Model from Othman and Owen (2001) as there is an element of religious obedience. Subsequently, the first hypothesis is formulated as follows:

\section{H1: There is a significant positive effect between service quality and loyalty.}

\subsection{Trust}

Koufaris and Sosa (2002) defined trust as a belief that consumers will find what they want from providers of goods and services. Wu and Liu (2007) further stated that trust is how providers of goods and services conduct activities and act by what is desired by consumers. In short, trust is the belief that one can rely on others (Pavlou, 2003). In Islamic banking, trust is the belief that Islamic banks are run using sharia principles that are clearly different from conventional banks. Trust is defined as a customer believing that Islamic bank operations are managed with the principles of honesty, fairness, and equality (Hoq et al., 2010).

Service Quality that does not meet the customer expectations will reduce the customer trust towards the providers of goods and services. Trust is a major determining factor in increasing loyalty (Walczuch et al., 2001; Kuusik et al., 2009) because it can impact customers to remain committed to the provider's goods and services for a long period of time. This research's results were by Wu and Liu's argument (2007), stating that there is a positive and significant effect between the 
levels of trust and loyalty. However, in another study, the trust had a minimal direct effect on loyalty (Ball et al., 2004), and it also had a negative relationship with customer perceptions (Jarvenpaa et al., 2000). Furthermore, a study conducted by Setyawati and Raharja (2018) found that not all trust dimensions were related to customer loyalty. Hence, the next hypothesis is as follows:

H2: There is a significant positive effect on trust and loyalty.

\subsection{Satisfaction}

Customer satisfaction is an important variable for determining customers to keep using a bank (Gil et al.. 2006). This is because satisfaction can affect customer decision to continue involving an institution (Ndubisi et al., 2009). Furthermore, Oliver (1999) stated that there is a positive relationship between satisfaction and loyalty. Satisfied consumers have an impact on repeating purchases of a product or service. If the product or service cannot meet the customer's expectations, it will reduce the customer trust for the providers of goods and services and will further affect the willingness to continue involving with the company.

The more customers meet their expectations during the use of services, the higher the probability that they will repeat purchases at the same company (Wong and Sohal, 2003). Hoq and Amin (2010), in their research on customer satisfaction, found that higher customer satisfaction leads to customer intentions and causes reluctance to switch to other banks. Thus, it can be concluded that satisfaction has a vital role to instill customer loyalty behavior. Subsequently, the next hypothesis is as follows:

\section{H3: There is a significant positive effect on satisfaction and loyalty.}

\subsection{The Effect of Religiosity as a Moderation}

There is a relationship between religion and consumer behavior, yet measuring religion as a variable for consumer research is difficult. However, religion's effect has been operationalized in the context of research in terms of religious affiliation and religiosity (Muslichah et al., 2013). Although identification as a variable is relatively simple, Wilkes et al. (1986) believed that religious affiliation is not sufficient in understanding the effect of religion on consumer behavior. In the Muslim world, religiosity greatly affects all types of management decisions and practices (Alam et al., 2011) expressed in prayer at work, being honest, respecting trust, and mutual support for each other's welfare (Beekun and Badawi, 2005).

The level of religiosity varies according to social factors such as religion and culture (Alam et al., 2011). Religiosity is also related to the level of perceived behavioral control exhibited by people in both social and organizational settings (Cohen et al., 2012; Cherry, 2006; Vitell, 2009). Employees who score high on religiosity tend to 
show higher perceived behavioral control (Walker et al., 2012). Vice versa, people who show a higher level of behavioral control are more likely to be affected by religious teachings and practices (Welch et al., 2006)

Studies of a religious issue as a banking selection criterion show different findings even among Muslims. According to Worthington et al. (2003), religious commitment is often stated as religiosity and is defined as a label for someone who obeys religious values, beliefs, and practices of worship and makes it a guide in taking action in everyday life. Studies conducted by Metawa and Al-Mosawwi (1998) and Bley and Kuehn (2004) found that religiosity is a major factor for customers to choose Islamic banks, and trust in religious teachings is the main impetus. Feras et al. (2018) found different things related to the effect of religiosity on loyalty. Religiosity is not the main determinant of loyalty to Islamic banks in Jordan. Meanwhile, religiosity as a practice of religious teachings also affects a sense of trust that Islamic banks are run with sharia principles of Islamic law.

In previous empirical studies, religiosity affects attitudes toward materialism (Cleveland and Chang, 2009), cultural identity (Lindridge, 2005), shopping behavior (Sood and Nasu, 1995), and consumer use of product information (Choi, Kale, and Shin, 2010). The findings highlight that consumers' purchasing behavior with a high level of religiosity is different from the behavior of those with a low level of religiosity. Souiden and Rani (2015) stated that individuals have different religiosity levels and can be divided into four categories: most religious, moderate, less religious, and non-religious. To integrate all of the notions, the next hypotheses are stated as follows:

H4: Religiosity moderates the relationship between service quality and customer loyalty.

H5: Religiosity moderates the relationship between customer trust and loyalty.

H6: Religiosity moderates the relationship between customer satisfaction and loyalty.

\subsection{Theoretical Framework}

Based on the research problems, phenomenon, and gap stated, the relationship between variables as a whole can be described in the following research framework model (Figure 2).

\section{Methodology}

This research used a positivist paradigm and a quantitative approach. The research type was explanatorily aiming to explain the causal relationship between several concepts or variables. This research's population was that all customers in the stateowned Islamic bank in Jakarta as most Islamic bank assets were in Jakarta. Stateowned Islamic banks (BUMN Islamic Banks) consisted of Shariah Mandiri, Shariah 
BRI, and Shariah BNI Banks. The population was unknown; the sampling method was conducted by non-probability sampling with a purposive sampling method.

Figure 2. Research Conceptual Framework Model

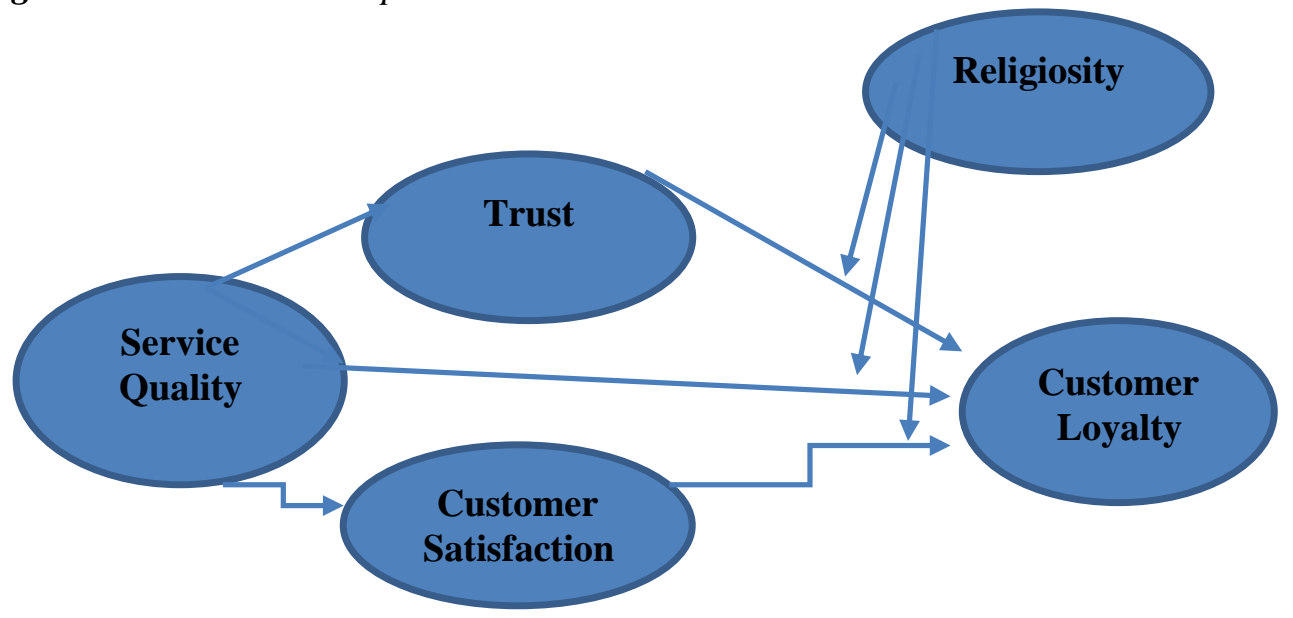

Source: Authors.

The number of samples in this research was determined using the rule of Hair (2014), i.e., 5-10 times the number of indicators, so the sample was 240. The data collection method utilized survey methods with questionnaire instruments (Saunder et al., 2016) to respondents who conducted transactions in Islamic banks.

Data analysis in this research used Partial Least Square (PLS), a covariance-based SEM (Structural Equation Model) with WarpPLS 6.0 software developed by Kock (2019). The PLS model's evaluation in this research included: (1) examination of the overall measure of fit model and (2) fit model measurement aiming to examine whether the research instrument was valid and reliable in explaining or reflecting latent variables. Latent variables were measured using reflective indicators so that the evaluation of the measurement model could be carried out by looking at the values of convergent validity, discriminant validity, and composite reliability. The advantages of using WarpPLS software were the additional new features making the WarpPLS program more powerful, especially in analyzing the moderation (Ghozali and Latan, 2014).

\section{Findings and Discussions}

\subsection{Respondents' Characteristics}

The purpose of the respondents' characteristics in this research was to describe Islamic bank customers in Jakarta based on demographics, i.e., by gender, age, education, income, and occupation (Table 1). 
Table 1. Characteristics of Respondents

\begin{tabular}{|l|l|l|}
\hline Characteristics of Respondents & Percentage (\%) \\
\hline Gender & Male & 49,2 \\
\cline { 2 - 3 } & Female & 50,8 \\
\hline \multirow{4}{*}{ Age } & $<25$ years old & 2,5 \\
\cline { 2 - 3 } & $26-32$ years old & 15,8 \\
\cline { 2 - 3 } & $33-40$ years old & 36,7 \\
\cline { 2 - 3 } & $>$ 40 years old & 45,0 \\
\hline \multirow{4}{*}{ Income } & High School & 5,0 \\
\cline { 2 - 3 } & Diploma & 3,3 \\
\cline { 2 - 3 } & Undergraduate & 30,0 \\
\cline { 2 - 3 } & Postgraduate & 61,7 \\
\hline \multirow{4}{*}{ Occupation } & $<5$ million IDR & 22,5 \\
\cline { 2 - 3 } & $5-10$ million IDR & 41,7 \\
\cline { 2 - 3 } & $10-15$ million IDR & 17,5 \\
\cline { 2 - 3 } & $>15$ million IDR & 18,3 \\
\hline \multirow{4}{*}{$\begin{array}{l}\text { Own Bank Account } \\
\text { other than Islamic Bank }\end{array}$} & Civil Servant & 25,0 \\
\cline { 2 - 3 } & Private Employee & 20,8 \\
\cline { 2 - 3 } & Professional & 35,8 \\
\cline { 2 - 3 } & Entrepreneur & 9,2 \\
\cline { 2 - 3 } & Others & 9,2 \\
\cline { 2 - 3 } & No & 89,2 \\
\hline
\end{tabular}

\section{Source: Authors.}

According to gender, characteristics of respondents showed no significant difference between men (49.2\%) and women (50.8\%) in choosing an Islamic bank. Meanwhile, according to age, the characteristics of respondents showed that the majority of respondents aged over 40 years by $45.0 \%$. It can be inferred that respondents whose age above 40 years old had a more realistic understanding of religion in using Islamic banks.

According to education, characteristics of respondents showed that the majority of respondents were highly educated (undergraduate and postgraduate) by $91.7 \%$, while those with a diploma and high school/vocational education were only $8.3 \%$. This demonstrated that most customers had relatively high levels of education, so that they had a fairly good understanding of Islamic banks.

Furthermore, according to income, respondents' characteristics showed that most respondents earned between 5-10 million rupiahs (41.7\%), and those who earned more than 15 million were also relatively high at $18.3 \%$. According to the occupation, respondents' characteristics showed that most respondents were professionals/consultants by $35.8 \%$, followed by civil servants at $25 \%$. This highlighted that respondents or the public showed their concern for Islamic banks to support business or economic activities even though the ownership of bank accounts other than Islamic banks was quite high, at $89.2 \%$. 


\subsection{Evaluation of Measurement Model}

In general, the structural model fit carried out in this research was adequate in which the p-value for Average Path Coefficient (APC), Average R-squared (ARS), and Average adjusted R-squared (AARS) was smaller than 0.001 ( $\mathrm{p}<0.001$ ) with the $\mathrm{APC}$ value $=0.498, \mathrm{ARS}$ value $=0.662$ and $\mathrm{AARS}$ value $=0.657$. Likewise, the average block VIF (AVIF) and Average full collinearity VIF (AFVIF) values generated were $\leq 5$, and still acceptable. Hence, there was no multicollinearity problem between indicators and between exogenous variables. This was also strengthened by the analysis model's ability shown by big Tenenhaus GoF index (0.730). Thus, it can be concluded that the overall model was good and could be accepted. Sympson's paradox ratio (SPR) index, R-squared contribution ratio (RSCR), and Statistical suppression ratio (SSR) produced values equal to 1, meaning that there was no causality problem in the model.

Evaluation of the model measurement results is presented in Table 2 shows that the measurement model met the convergent validity since the loading factor of all variables examined was greater than 0.70, and AVE was all greater than 0.50 . Likewise, the composite reliability and Cronbach Alpha values produced by all constructs were also great; $>0.70$, so that it met the internal consistency reliability.

Table 2. Evaluation of Fit Model Measurement

\begin{tabular}{|c|c|c|c|c|c|}
\hline \multirow[t]{2}{*}{ Variable } & \multirow{2}{*}{$\begin{array}{l}\text { Indicator/ } \\
\text { Item }\end{array}$} & \multicolumn{2}{|l|}{ Validity } & \multicolumn{2}{|l|}{ Reliability } \\
\hline & & $\begin{array}{l}\text { Loading } \\
\text { Factor }\end{array}$ & AVE & $\begin{array}{l}\text { Composite } \\
\text { Reliability }\end{array}$ & $\begin{array}{l}\text { Cronback } \\
\text { Alpha }\end{array}$ \\
\hline \multirow{6}{*}{ Religiosity } & Rel1 & 0,753 & \multirow{6}{*}{0.817} & \multirow{6}{*}{0,853} & \multirow{6}{*}{0.915} \\
\hline & Rel2 & 0,823 & & & \\
\hline & Rel3 & 0,805 & & & \\
\hline & Rel4 & 0,622 & & & \\
\hline & Rel5 & 0,846 & & & \\
\hline & Rel6 & 0,810 & & & \\
\hline \multirow{9}{*}{ Service Quality } & $\mathrm{Sq} 1$ & 0,826 & \multirow{9}{*}{0.835} & \multirow{9}{*}{0,954} & \multirow{9}{*}{0.945} \\
\hline & $\mathrm{Sq} 2$ & 0,805 & & & \\
\hline & $\mathrm{Sq} 3$ & 0,885 & & & \\
\hline & $\mathrm{Sq} 4$ & 0,922 & & & \\
\hline & Sq5 & 0,895 & & & \\
\hline & Sq6 & 0,742 & & & \\
\hline & Sq7 & 0,863 & & & \\
\hline & Sq8 & 0,816 & & & \\
\hline & $\mathrm{Sq} 9$ & 0,740 & & & \\
\hline \multirow{3}{*}{ Satisfaction } & Sat1 & 0,871 & \multirow{3}{*}{0.912} & \multirow{3}{*}{0,937} & \multirow{3}{*}{0.898} \\
\hline & Sat2 & 0,914 & & & \\
\hline & Sat3 & 0,948 & & & \\
\hline \multirow[t]{2}{*}{ Trust } & Trs1 & 0,879 & \multirow[b]{2}{*}{0.926} & \multirow[b]{2}{*}{0,947} & \multirow[b]{2}{*}{0.916} \\
\hline & Trs2 & 0,951 & & & \\
\hline
\end{tabular}




\begin{tabular}{|l|l|l|l|l|l|}
\hline & Trs3 & 0,945 & & & \\
\hline Loyalty & Loy1 & 0,899 & 0.914 & 0,721 & 0.901 \\
\hline
\end{tabular}

\section{Source: Authors.}

\subsection{Analysis and Testing Results}

Data were analyzed by using WarpPLS software, and the results are presented in a research conceptual framework model as shown in Figure 3, while the path coefficient of the relationship between variables is presented in Table 3.

Figure 3. Results in a conceptual framework model

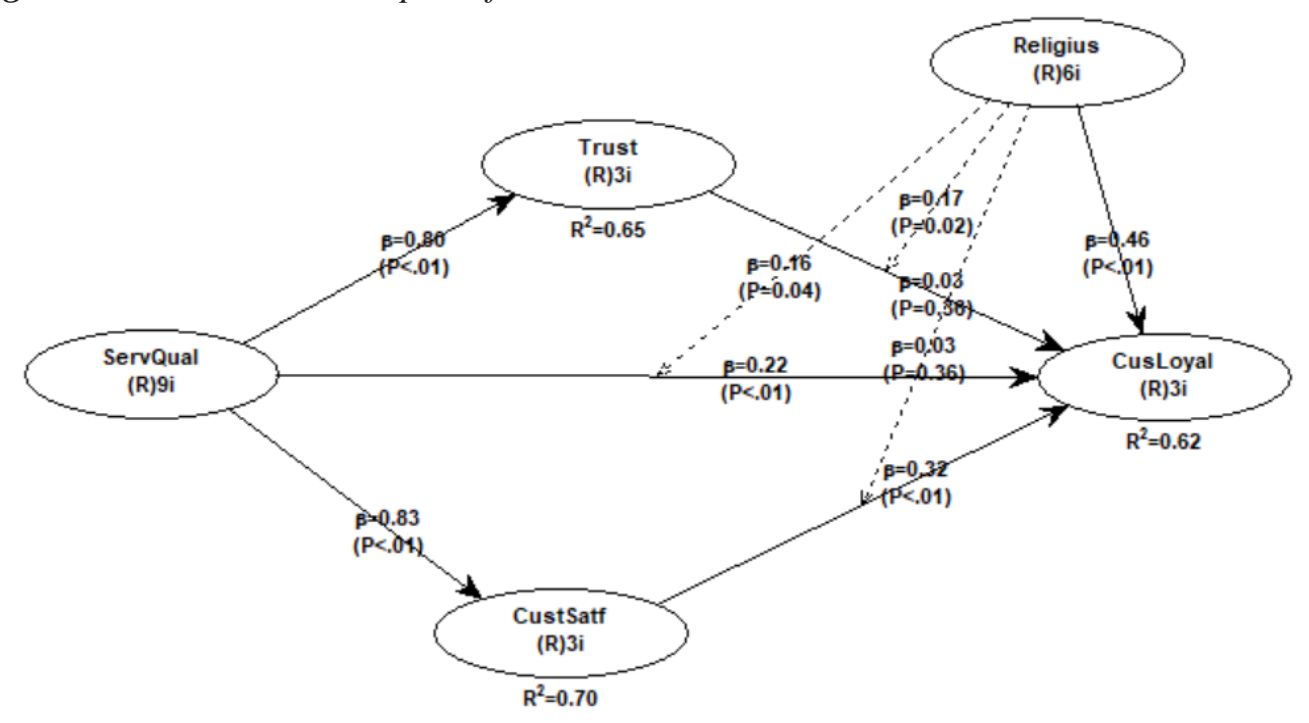

Source: Authors.

Table 3. Path coefficients of direct and indirect effects and moderation

\begin{tabular}{|c|c|c|c|c|c|c|c|c|}
\hline \multicolumn{5}{|l|}{ Direct Effect } & \multicolumn{4}{|c|}{ Indirect Effect } \\
\hline Indeependent & Dependent & Coef & $\begin{array}{l}\mathrm{P} \\
\text { Value }\end{array}$ & Info & $\begin{array}{l}\text { Moderat } \\
\text { ion }\end{array}$ & Coef & $\begin{array}{l}\mathrm{P} \\
\text { Value }\end{array}$ & Info \\
\hline $\begin{array}{l}\text { Service } \\
\text { Quality }\end{array}$ & \multirow{4}{*}{$\begin{array}{l}\text { Customer } \\
\text { Loyalty }\end{array}$} & 0.36 & $<0.01$ & Sig & \multirow{4}{*}{$\begin{array}{l}\text { Religiou } \\
\text { sity }\end{array}$} & 0.16 & 0.04 & Sig \\
\hline $\begin{array}{l}\text { Customer } \\
\text { Satisfaction }\end{array}$ & & 0.31 & $<0.01$ & Sig & & 0.03 & 0.36 & $\begin{array}{l}\text { No } \\
\text { Sig }\end{array}$ \\
\hline $\begin{array}{l}\text { Customer } \\
\text { Trust }\end{array}$ & & 0.03 & 0.36 & $\begin{array}{l}\text { No } \\
\text { Sig }\end{array}$ & & 0.17 & 0.02 & Sig \\
\hline Religiosity & & 0.46 & $<0.01$ & Sig & & - & - & - \\
\hline \multirow[t]{2}{*}{$\begin{array}{l}\text { Service } \\
\text { Quality }\end{array}$} & $\begin{array}{l}\text { Customer } \\
\text { Trust }\end{array}$ & 0.80 & $<0.01$ & Sig & & - & - & - \\
\hline & $\begin{array}{l}\text { Customer } \\
\text { Satisfaction }\end{array}$ & 0.83 & $<0.01$ & Sig & & - & - & - \\
\hline
\end{tabular}

Source: Authors. 
Table 3 shows that service quality, customer satisfaction, and religiosity had a positive and significant direct effect on customer loyalty because $p$-value had a value of $<0.01$ or $p$-value $<$ level of significance $(\alpha=5 \%)$. The direct effect of service quality on customer trust and customer satisfaction also positively and significantly affected the customer. Nonetheless, the direct effect of customer trust on customer loyalty was not significant because the p-value had a value of $>0.01(0.36)$ or $p$ value was $>$ level of significance $(\alpha=5 \%)$. Furthermore, the results showed that religiosity moderated the relationship between service quality and loyalty because the moderation coefficient was 0.16 (positive) and p-value $(0.04)<$ level of significance $(\alpha=5 \%)$. Besides, religiosity also moderated the relationship between trust and loyalty because the moderation coefficient was 0.17 (positive) and p-value $(0.02)<$ level of significance $(\alpha=5 \%)$. However, religiosity failed to moderate customer satisfaction on loyalty because the p-value of 0.36 was greater than the significance value $(\alpha=0.05)$.

\subsection{Discussion}

This research indicated that service quality had a positive and significant direct effect on customer loyalty. This finding was supported by Junaedi et al. (2012), Zakiy (2017), Hartini and Meilani (2019), and Ahmed and Kanwal (2019), who stated that service quality has a significant effect on customer loyalty towards Islamic banks. This means that Islamic banks must be able to maintain and improve the service quality as it will impact customer decision to continue using the service and further increase loyalty to the Islamic banks.

Furthermore, this research's findings also confirmed previous research arguing that service quality is an antecedent of loyalty (Meesala and Paul, 2018; Murali et al., 2016). The results were also consistent with previous studies conducted by Dkudiene et al. (2015) and Kian et al. (2013). The addition of compliance and cultural indicators in this research resulted in service quality indicators of Islamic banks with their own uniqueness in serving the customers. Compliance in Islamic banking with muamalat principles regulated in the Al-Quran and Sunnah made its own attraction for its customers. Furthermore, good service quality would cause Islamic bank customers to meet their expectations, which could be improved by providing good quality services.

Moreover, customer satisfaction had a positive and significant direct effect on loyalty. This demonstrated that the more satisfied the customer, the more loyal the customer would be to the Islamic bank. When customers were satisfied with the services provided by Islamic banks, they would be loyal and recommend the Islamic bank to others. This finding supported several previous studies such as Han and Hyun (2018), Meesala and Paul (2018), and Forinstance and Kamran-Disfanietal (2017), arguing that customer satisfaction is the antecedent of loyalty. This research indicated that to gain loyalty from customers, companies must pay attention to several factors, including satisfaction as the main point. Increased customer 
satisfaction resulted in increased customer loyalty. In other words, the higher customer satisfaction, the higher customer loyalty would be.

Service quality had a positive and significant direct effect on trust, so the higher the service quality provided by Islamic banks, the higher the customer trust towards Islamic banks. This finding was supported by Sahadev and Purani (2008), Sadeh et al. (2011), and Rizwan et al. (2014), stating that service quality has a significant effect on customer trust. However, Misbach (2017) found different results, as there were differences in measuring service quality indicators used in his research. This research used Carter's measurement, while Misbach (2017) used the service system, responsiveness, and reliability indicators adopted from the research of Abdullah et al. (2011) on Malaysia's banking sector.

In this research, the trust did not have a significant effect on loyalty. This happened because the image, participation, and public awareness of Islamic banks were still low due to the Muslim community's lack of understanding of Islamic bank products, systems, and observance of Islamic religious law or religiosity. This finding was supported by Ball et al. (2004), demonstrating that trust has an insignificant direct effect on loyalty and has a negative relationship with customer perceptions (Jarvenpaa et al., 2000). Furthermore, a study conducted by Setyawati and Raharja (2018) found that not all trust dimensions are related to customer loyalty.

This research also showed that religiosity had a significant and direct effect on loyalty (Table 3). This finding was supported by Metawa and Al-Mosawwi (1998) studying Islamic bank customers in Bahrain. They stated that religiosity is a major factor in the discourse in choosing and using Islamic banks. In addition, Bley and Kuehn (2004) also supported the finding of this research in which they examined Muslim respondents in the United Arab Emirates and found that beliefs mainly drove preference for Islamic banks in religious teachings.

In addition, religiosity had a positive and significant effect on the relationship between service quality and trust in loyalty. These results revealed that service quality and trust were able to reflect well on loyalty by showing a higher religiosity level. Therefore, religiosity had an important role and was able to increase customer loyalty towards Islamic banks significantly. These results were supported by a study conducted by Gundolf and Filser (2013), stating that religiosity has a positive impact on company promotion, especially in the financial service sector (Dyreng et al., 2012). Nonetheless, this research also showed that religiosity did not significantly impact the relationship between customer satisfaction and loyalty. This was possibly because some Muslims began to put aside Islamic values and ethics in all aspects of life (Sabri, 2001). Besides, religious factors were not considered and had a weak impact on consumer decisions (Souiden and Rani, 2015).

This finding was supported by Nasrullah's study (2015) on Islamic Branding, which stated that religiosity as moderation weakens the relationship between Islamic 
branding and consumer decision variables on Islamic products. According to Nasrullah's explanation (2015), because Indonesians tend to be consumptive, they prioritize desires over needs, so in terms of religiosity, they have not made religion as the way of life.

\section{Conclusion}

The hypothesis testing, based on established theories using data representing the daily experiences of consumers or customers, is expected to increase public participation in banking, especially in Muslim societies. This research highlighted the importance of religiosity that fosters ethical norms to encourage and increase customer loyalty. Studies have been conducted on religiosity's importance in encouraging consumer behavior (Kashif et al., 2015). In practice, these findings suggest that periodic and systematic religiosity can build and improve consumer behavior, especially in increasing customer loyalty to Islamic banks.

This research's important contribution is the position of religiosity as a moderating variable in the consumer decision-making scheme of Islamic banks. This research proposed that thorough and sensitive promotion of religious activities towards customers can help spread and strengthen ethical behavior's moral norms. Meanwhile, considering that religiosity does not significantly affect the relationship between customer satisfaction and loyalty; hence, increasing the religiosity level and its relation to ethics is important. This demonstrates that ethics is contagious and that religion (i.e., religious activities, devotion to rituals, and belief in doctrine) facilitates and accelerates the transmission of understanding Islamic banks. Therefore, it is advisable to conduct continuous education to the consumers regarding Islamic banks so that Islamic banks should expose religiosity to increase loyalty and, most importantly, improve their services and trust.

\section{Limitations and Future Research Directions}

The limitation of this research is the unit of analysis, namely the government-owned Islamic bank customers. The generalization is only limited to state-owned Islamic banks; it would be more comprehensive if the research involved all Islamic bank customers. Another limitation is that the research is only conducted in Jakarta, so the generalization is only limited to Jakarta; further research is better if carried out in all provinces in Indonesia.

Also, promotions carried out by Islamic banks through various media are still far behind conventional banks. Considering that Islamic banks' existence is relatively new compared to conventional banks, intensive promotion and education are needed to all levels of society to minimize dependence on conventional banks. Further research is recommended to use demographic personality as control or moderating variable. 


\section{References:}

Amin, M., Isa, Z., Fontaine, R. 2013. Islamic Banks: Contrasting the drivers of customer satisfaction on Image, trust, and loyalty of Muslim and non-muslim customer in Malaysia. International journal of bank marketing, 3(2), 79-97.

Awan, H., Shahzad, B.K. 2011. Customer's criteria for selecting an Islamic bank: evidence from Pakistan. Journal of Islamic Marketing, 2(1), 14-27.

Basalamah, M.R., Moeljadi, M., Sudjatno, S. 2018. The Effect of Service Quality and Relationship Marketing Towards Customer Loyalty for Sharia Banking (Sharia Banking Study in Makassar Indonesia). International Review of Management and Marketing, 8(1), 107-114.

Beerli, A., Martín, J., Quintana, A. 2004. A model of customer loyalty in the retail banking market. European Journal of Marketing, 38(1/2), 253-275.

Boonlertvanich, K. 2019. Service quality, satisfaction, trust, and loyalty: the moderating role of main-bank and wealth status. International Journal of Bank Marketing, 37(1), 278-302. DOI 10.1108/IJBM-02-2018-0021.

Casalao, L.V., Flavian, C., Guinalu, M. 2008. Promoting Consumers Participation in Virtual Brand Communities: A New Paradigm in Branding Strategy. Journal of Marketing Communication, 14(1), 19-36.

Castro, J.M.P. 2006. Relationship Marketing and Consumer Behavior In Fast-Moving Consumer Goods. Disertasi, Universidade do Algarve.

Dowling, G. 2002. Customer Relationship Management. California Management Review, 44(3).

Durkin, D.M. 2005. The Loyalty Advantage. ISBN 0-8144-0817-6.

Echchabi, A., Aziz, H.A. 2012. The relationship between Religiosity and Customer Adoption of Islamic Banking Service in Maroko. Arabian Journal of Business and Management Review, (OMAN Chapter), 1(10).

Echchabi, A., Olaniyi, O.N. 2012. Using Theory of Reasoned Action to Model of Patronisation Behaviour of Islamic Banks' Customer in Malaysia. Research Journal of Business Management, 6(3), 70-82.

Feras, M.I., Alwr, Mazuri Abd Ghani, Samar, Rahi. 2018. Service quality in Islamic banks: The role of PAKSERV model, customer satisfaction and customer loyalty. Accounting, 4.

Ghozali, I., Latan. 2014. Partial Least Squares concepts, techniques and programs Smart PLS 3.o for empirical research. Diponegoro University Press.

Global Islamic Index Thomson Reuters, 2018. Data.

Hair, J.F., Hult, G.T.M., Ringle, C.M., Sarstedt, M. 2017. A Primer on Partial Least Squares Structural Equation Modeling (PLS-SEM), $2^{\text {nd }}$ edition. Thousand Oaks, Sage.

Hayes, B.E. 2011. Lessons in LOYALTY. Quality Progress, 44(3).

Hoq, M.Z., Sultana, N., Amin, M. 2010. The effect of trust, customer satisfaction and image on customers' loyalty in Islamic Banking Sector. South Asian Journal of management, 17(1), 70-93.

Infobanknews. 2010. Retrieved from: http://www.infobanknews.com/2010/12/.

Jones, T., Sasser, W.E.Jr. 1994. Marketing (Second Edition). McGrow Hill Inc.

Jaiswal, A.K., Niraj, R. 2007. Examining the Nonlinear Effects in Satisfaction-LoyaltyBehavioral Intentions Model, Research and Publications. Indian Institute of Management. Ahmedabad-380 015 India. 
Kashif, M., Zarkada, A., Thurasamy, R. 2017. The moderating effect of religiosity on ethical behavioural intentions: An application of the extended theory of planned behaviour to Pakistani bank employees. Personnel Review, 46(2), 429-448.

Kashif, M., Wan Shukran, S., Rehman, M., Sarifuddin, S. 2015. Customer satisfaction and loyalty in Malaysian Islamic banks: a PAKSERV investigation. International Journal of Bank Marketing, 33(1), 23-40.

Kiseleva, E.M., Nekrasova, M.L., Mayorova, M.A., Rudenko, M.N., Kankhva, V.S. 2016. The Theory and Practice of Customer Loyalty Management and Customer Focus in The Enterprise Activity. International Review of Management and Marketing, 6(6), 95-103.

Koch, N. 2017. Warp PLS 6 user manual. Toredo, Texas. USA.

Koch N., Hadaya, P. 2018. Minimum sample size estimation in PLS-SEM: The inverse square root and gamma-exponential methods. Information Systems Journal, 28(1), 227-261.

Kotler, P., Keller, K.L. 2016. Marketing Managemen, 15th Edition. Pearson Education Inc.

Koufaris, M., Sousa, W.H. 2002. Costumer Trust online. Examining the role of the experience with the website. CIS working papers Series.

Kuusik, A. 2007. Affecting Customer loyalty: Do different factors have various influences in different loyalty levels? Tartu University Press, Order No. 366.

Kuusik, A., Varblane, U. 2009. How to avoid customers leaving: the case of the Estonian Telecommunication industry. Baltic Journal of Management, 4(1).

Lee, C., Lee, J., Yoon, Y. 2010. Measuring festival quality and value affecting visitors' satisfaction and loyalty using a structural approach. International Journal of Hospitality Management, 29(2), 335-342.

Leverin, A., Liljander, V. 2006. Does relationship marketing improve customer relationship satisfaction and loyalty? International Journal of Bank Marketing, 24(4), 232-251.

Lovelock, C. Wirtz, J. 2011 Service Marketing: People, Technology, Strategy. Prentice Hall, Tokyo.

Luo, X., Bhattacharya, C.B. 2006. Corporate Social Responsibility, Customer Satisfaction, and Market Value. Journal of Marketing, 70(4), 1-18. http://www.jstor.org/sTabel/30162111

Mahardika, I.M. 2018. Determination Loyalty Based on Service Quality, Customer Satisfaction and Trust at BPR Bukit Tanjung Badung. International Journal of Contemporary Research and Review, 9(02), 20473-20484. https://doi.org/10.15520/ijcrr/2018/9/02/424

Marshall, N.W. 2010. Commitment, Loyalty And Customer Lifetime Value: Investigating The Relationships Among Key Determinants. Journal of Business \& Economics Research (JBER), 8(8). https://doi.org/10.19030/jber.v8i8.753

Metawa, S.A., Almossawi, M. 1998. Banking Behavior of Islamic bank customers: perspectives and implications. International journal of bank marketing, 16(7), 299313.

Naeem, H., Akram, A., Saif, M.I. 2009. Service Quality and its Impact on Customer Satisfaction: An Empirical Evidence from the Pakistani Banking Sector. International Business \& Economics Research Journal (IBER), 8(12).

Ndubisi, N.O., Malhotra, N.K., Chan, K.W. 2009. Relationship marketing, customer satisfaction and loyalty: a theoretical and empirical analysis from an Asian perspective. Journal of International Consumer Marketing, 21(1), 5.

Okumus, H.S., Genc, E. 2013. Interest Free Banking in Turkey: A Study of Customer Satisfaction and Bank Selection. The Europen Scientific Journal, 9(16), 144-166. 
Othman, A,Q., Owen, L. 2002. The Multi Dimensionality of Carter Model to Measure Customer Service Quality (SQ) in Islamic Banking Industry: A Study in Kuwait Finance House. International Journal of Islamic Financial Services, 3(4).

Otoritas Jasa Keuangan. 2019. Indonesian Banking Statistics, June.

Palmatier, R.W. et al. 2006. Factors Influencing the Effectiveness of Relationship Marketing: Meta Analysis. Journal of marketing, 70, 136-153.

Pavlou, P.A. 2003. Consumer Acceptance of Electronic Commerce: Integrating Trust and Risk with the Technology Acceptance Model. International Journal of Electronic Commerce, 7(3), 69-103.

Pollack, L.B. 2009. Linking the hierarchical service quality model to customer satisfaction and loyalty. Journal of Services Marketing, 23(1), 42-50.

Rahmani-Nejad, L., Firoozbakht, Z., Taghipoor, A. 2014. Service Quality, Relationship Quality and Customer Loyalty (Case Study: Banking Industry in Iran). Open Journal of Social Sciences, 2, 262-268. http://dx.doi.org/10.4236/jss.2014.24028.

Ravichandran, K., Tamilmani, B., Kumar, S.A., Prabakaran, S. 2010. Influence of Service Quality on Customer Satisfaction, Application of Servqual. International Journal of Business and Management, 5(4).

Razimi, M.S.A., Romle, A.R. 2017. Non-Muslim Perception on Islamic Banking Products and Services in Malaysia. World Journal of Islamic History and Civilization, 7(1), 07-11.

Reichheld, F.F., Markey Jr, den H. 2000. The loyalty effect - The relationship between loyalty and profits. European Business Journal, 12, 173-179.

Reichheld, F.F. 1996. The Loyalty Effect: The Hidden Force Behind Growth, Profts, and Lasting Value. Bain and Company, Inc.

Rizwan. 2014. Incorporating Attitude Towards Islamic Banking in an Integrated Service Quaity, Satisfaction, Trust and Loyalty Model. International Journal of Accounting and Financial Reporting, 4(2), 456-477.

Shafie Shahril, Wan Nursofiza Wan Azmi and Sudin Harun. 2004. Adopting and Measuring Customer Service Quality in Islamic Banks: A Case Study of Bank Islam Malaysia Berhad. Journal of Muamalat and Islamic Finance Research, 1(1).

Saunder, M., Lewis, P., Thornhill, A. 2016. Research methods for business Seventh edition. Pearson, London.

Schneider, B. 1980. The service organization: climate is crucial. Organizational Dynamics, 54.

Setyawati, S.M., Raharja, C. 2018. Trust Dimensions Model in Creating Loyalty stage for Service Consumers of Sharia Rural Banking. European Research Studies Journal, 11(1).

Souiden, N., Rani, M. 2015. Consumer attitudes and purchase intentions toward Islamic banks: the influence of religiosity. International Journal of Bank Marketing, 33(2), 143-161.

Wong, A., Sohal, A. 2003. Service quality and customer loyalty perspectives on two levels of retail relationships. Journal of Services Marketing, 17(5), 495-513.

Walczuch, R., Seelen, J., Lundgren, H. 2001. Psychological Determinants for Consumer Trust in E-Retailing. Proceedings of Eighth Research Symposium on Emerging Electronic Market, 1-21.

Wugayan, A., Pleshko, L.P. 2010. A Study of Satisfaction, Loyalty, and Market Share Kuwait Banks. University Proceedings of the Academy for Studies in International Business, 10(1). 